\title{
REPRESENTATION OF DEATH IN EDGAR ALLAN POE AND EMILY DICKINSON
}

Sudha Swarnakar ${ }^{1}$

Abstract: This essay reflects on the representation of death in two major writers of American literature; Edgar Allan Poe and Emily Dickinson. The discussion is based on comparative theory and thematic analysis. As Emily Dickinson has tried her hand only on poems I purposely avoid the huge body of fictional writing of Poe and limit this work only to his poems. The main argument is constructed around the thought that though both poets are obsessed with death, and a number of their works knit around the theme of death they do not share the same idea about the death. Their poetic world shows that they see and present death in a very different way.

Key words: Death, Melancholy, Poe, Dickinson.

Resumo: Este artigo reflete sobre a representação do tema da morte nas obras de dois escritores norte americano; o Edgar Allan Poe e Emily Dickinson. Como instrumento de pesquisa e apoio teórico buscamos a teoria comparada e estudo temático. Para ser justo na nossa comparação com Emily Dickinson, que nunca entro no mundo de ficção e ficou escrevendo só poemas, tentamos não entrar no mundo de ficção de Edgar Allan Poe e limitar a discussão só para os poemas dele. $\mathrm{O}$ argumento principal neste trabalho se constrói ao redor a idéia que apesar de ambos os poetas ser obcecados com a morte, como a constante presença da morte nos trabalhos deles prova. Percebemos que a maneira no qual eles apresenta a morte é bem diferente. Palavras-chave: Morte, Melancolia, Poe, Dickinson.

In his article, “Textual Analysis: Poe's Valdemar” Roland Barthes (1988, p. 153) rightly observes, "who could avoid being touched by a text whose declared 'subject' is death?" In the works of both Edgar Allan Poe and Emily Dickinson the constant presence of death and the popularity of both poets is a simple proof in favor of Barthes. Death and love have been very popular themes in literature. However, it seems that both Poe and Dickinson were the passionate lovers of Death. Yet to talk about death in Emily Dickinson and Edgar Allan Poe seems to present two different situations two different realities. Contrary to Poe who sees the death as the cause of lament, sorrow and pain, Dickinson sees it as a companion or the moment to go back to the life and refresh the pleasant memories.

1 Ph. D. em Teoria Comparada, Warwick, England. Professora Titular da Universidade Estadual da Paraiba - UEPB. Atua na área de gênero, estudos comparativos envolvendo literatura Inglesa, Americana, Canadense, Brasileira e Indiana (Hindi e Sânscrito). Endereço eletrônico: suswarna2001@yahoo.co.uk. 
I propose to make a comparison between Edgar Allan Poe and Emily Dickinson to see how death is presented by these two poets. The poems I have chosen are "The Raven" and "Annabel Lee" by Poe and "Because I Could Not Stop for Death", "Dying", "I Felt a Funeral in my Head" and "I heard a Fly buzz -when I died" by Emily Dickinson. In case of Poe the choice was easy as these are the only poems which knit around death. However, the abundance of poems on death in Emily Dickinson made it difficult to choose a few. I select these poems as they present different aspects of death and also seem to support my argument.

Those of us who work within the field of comparative literature know that in comparative criticism it is a common practice to study literary works set in same time period but to compare works from same linguistic and socio-cultural context is normally not accepted. Hence what I am trying to propose here, a comparison between poets from same language, same culture and same literary tradition, might fall out of the scope of comparative literature. However, in Comparative Study such work will not be discarded. Comparative Study goes back to its origin in Greek tradition and expands frontiers which are well locked up by comparative literature. Despite not following the practice of comparative literature, in strict sense, I am trying to compare these two poets to show how a comparative analysis, by highlighting the similar and opposite elements in two writers, makes one to see them from a totally different angle.

Commenting on the importance of comparison, in his critical essay, "On the Comparison of Interliterary Configurations", Armin Paul Frank (2003) observes, "comparison is essential for an understanding of every significant work in almost any literature because the authors themselves have always written more or less comparatistically." Moreover, as I propose to look at the thematic unity in these two poets I am not going away from the well trodden path of comparative criticism known as 'thematic study'. In recent years much discussion in comparative literature has focused on themes and movements. While some critics, for instance Koelb and Noakes (1988), have tried to argue that present trend in comparative literature shows a decline in thematic studies. Others, S. S. Prawer (1973, p. 102) and Susan Bassnett (1993, p. 116-117) see that the "study of themes [...] continues unabated".

It is interesting to note that apart from some brief comparative comments in a passing way I could trace only one small paper by Wendy S. Flory, titled "Rehearsals for Dying in Poe and Emily Dickinson" where she offers a comparative analysis of these two poets, focusing on the topic of death. A profound study of Poe and Emily Dickinson is yet to come. The reasons for lack of such work can be attributed to the fact that in American tradition of romantic poets, Poe and Dickinson stand quite afar. Also majority of Poe's work was published while he was alive whereas only seven of Dickinson's poems were published during her lifetime 30

A Cor das Letras - UEFS, n. 8, 2007 
as she kept herself in obscurity. Poe and Dickinson also differ widely not only in their linguistic, historical, and cultural constitution but also in their patterns of writing. Though the objective is not to enter in the merit of the question yet it is not possible to ignore these facts completely. A comparison, which should take similarities and differences carefully into account, may help to have a better understanding of these two poets and their portrayals of Death.

First of all I would like to call attention to the facts which made these two writers so different. Though by doing so, again, I am breaking the norms. In critical practice it is normally not approved to analyze a literary work in the light of biographical facts of a writer. In his essay on "Samson Agonistes" Tinker observes that the poet is "concerned with poetry, not with autobiography, and makes use of what he needs for his creative purpose, whether or not it be true to the actual events of his life." However, it seems inevitable to omit certain life facts as we look at these two poets. In case of both Poe and Dickinson, their lives seem to have a strong influence on their attitudes towards death.

Compare to a protective home of Miss Dickinson where she abode with parents, brother, and sister, Poe's life paints a very dismal picture. As his biography shows his first encounter with death occurs at a very early age, "Poe was orphaned before he was three." Moreover, this three years old child has an encounter with death in a very strange circumstance where he "spent more than two days with the corpse before someone else showed up." When his mother died Poe was in the room, with dead body and his little brother.

In one of his poems titled "Alone" Poe gives voice to this acute sense of being alone as he says:

From childhood's hour I have not been

As others were; I have not seen

As others saw; I could not bring

My passions from a common spring.

It seems that this stunning encounter with death made Poe for ever a lonely person and death marked him so deeply that both his prose and poetry present it in one form or another. Though it cannot be affirmed, as we do not have exact dates of her poems yet through what the poems allude to, one can guess that death in Miss Dickinson's writing enters at much later stage.

Second point which calls my attention as I look at these two poets is the way they led their life. Contrary to Miss Dickinson, who led a secluded life for most part of her life, had lived in a self imposed isolation in her house or rather in 'her room', and had dropped the curtains closing any communication with outside world, Poe led his life as a constant traveler. Soon after the death of his parents, still a child, he moves from Boston, his birth place, to Virginia. Later, working 
most part of his life as a journalist, Poe not only travels to and fro between North and South of America he also comes into closer contact with people and writing of this vast land. In this sense Poe, the well known writer and journalist, in constant contact with American people, presents an opposite panorama from one we see in case of Miss Dickinson. Yet it is strange that contrary to Emily Dickinson who gets a warm farewell from her close people, at his last hours Poe is lonelier than her. He dies in a hospital bed without any close relative or a friend as alone as he might have been at the time of his mother's death ${ }^{2}$.

Third point to note is that contrary to Poe who published his first work 'Tamerlane and Other Poems' while he was only seventeen years old. Emily Dickinson guarded most of her writing as a close secret and we do not know the exact dates of her poems. Even those who were intimate to her, for instance her sister or brother, had no knowledge of the vast writing she left upon her death. Focusing on an essay by Adrienne Rich 'Vesuvius at Home: The Power of Emily Dickinson' Schweickart calls attention to three questions which puzzle Rich: "Why did Dickinson go into seclusion? Why did she write poems she would not publish? What mean these poems [...]" what can be admired as an act of courage for a young boy of seventeen cannot be interpreted as a cowardly act on part of Emily Dickinson. Her seclusion and keeping her writing a secret allude towards her being timid or fragile, suppositions which might not get support in her writing. One strong reason might be her chief critic Thomas Wetworth Higginson, who gave her an advice to change her style when she made her first effort to publish her poems. This suggestion might have discouraged Emily Dickinson from making her work public.

Fourth point can be charted is the choice of literary genre in which these two poets express themselves. Contrary to Poe who had been editor of several journals, an important critic in his own time, a prose master and a fascinating poet, Emily Dickinson poured all her poetic skill in one form of writing; poetry. Moreover, Poe without a doubt is one of the major writers in Romantic tradition whereas Emily Dickinson seems to be free from the Romantic ties as Eunice Glenn (1943, p. 587) observes, "it seems fairly clear [...] that she is free from the limitations of the romantic poet". After justifying her observation with a number

2 Death becomes a mystery in his own death. Most of literary anthologies ignore the fact and medical account presented by the doctor who attended Poe during last four days of his life. The medical report and the doctor's account affirm that Poe was brought to the hospital in an unconscious state. After four days he dies in a hospital bed and not in the street as is generally believed. Second the medical report states he had no alcohol at least fifteen days prior to his death and third the reason for his death was a chronic disease not very well known till his time. For details on Poe's death see the web page by E. A. Poe Society of Baltimore; Burton Pollin, Broadway Journal www.eapoe.org. Prof. Matthew Pearl in his recent novel The Poe Shadow (London, Random House, 2006) fictionalizes the mystery involved with Poe's death. 
of reasons the critic summarizes "her liberty in the use of words would hardly be sanctioned by the typically romantic poet, for fear of being "unpoetic" and not "great" and "beautiful".

Lastly, what calls our attention is the way both these poets entitled their poems. It seems that the desire to remain in dark led Miss Dickinson not to select a title for her poems. Almost invariably the titles chosen by her editors are all either the numbers or the first lines of her poems. On the contrary Poe selects his titles very carefully. In his essay on "The Poetic Principle" he observes that 'a poem deserves its title only inasmuch as it excites, by elevating the soul' (1951, p. 383).

Despite these contrasts what calls our attention is a number of similarities between these two poets. An attention to these similarities was first called by Martin Steinmann Jr. and Gerald Willen (1962, p. 616). In a passing way, comparing Edgar Allan Poe, Walt Whitman and Emily Dickinson, Steinmann and Willen suggest three common points between these poets. First, they were born in [New] England, second, 'they were little known and where known little admired' and third, they were innovators and 'in one way or another they, were like the Victorians, heirs of the romantics'. As Steinmann and Willen's comparison also included Walt Whitman it seems they did not include one more point, common at least between Poe and Dickinson; their fascination with Death. As Flory (1973, p. 13) comments both Edgar Allan Poe and Emily Dickinson frequently sought to convey the experience of death. Both believed that the search "for the meaning of human existence" would continue after death; and both "consistently recur to states of paralysis and vertigo".

Lois Banner (FLORY, 1973, p. 14), a contemporary historian, examines the practices and values of beauty especially as they relate to the nineteenth-century American woman. The historical documents she analyzes provide useful information for understanding both Poe and Dickinson.

"Death" in common understanding, can be interpreted as an external object or external identity whereas "dying" can be perceived as a process which can be external as well as internal; something happening to others or happening to one self. These two phenomena, though not "two" in scientific terminology, from literary point of view present the binary aspect. "Death" and "dying" are the elements that impose the difference we encounter in the poetic world of Poe and Dickinson.

Poe is renowned for his fascinating short stories of horror and terror. Death seems to impress him so much that it enters into his world in varied forms and in many of them it plays a remarkable role. For instance "The Masque of red Death", "The Black Death", The Tale Tell Heart" to name a few. Looking at vast writing of Poe we note that he hardly writes about love. Death and terror are the two most favored topics in Poe's work. His favorite theme remains death and almost in all of 
his tales have variations of this theme. What he tries to do through his tales specifically is to inflict death and the fear of the unknown on his audience.

In his fiction it comes slowly 'like a thief in the night' creating an atmosphere of horror and terror. However, as the objective of the present work is to compare Poe and Dickinson I leave aside Poe' s fiction. Though, he gives only fifty poems to the world in contrast to a large body of fiction it is interesting that Poe considers himself as a poet and admits that "poetry has not been a purpose but a passion" for him (STERN, p. 586). The melancholy associated with loss and bereavement, which normally dominates his poems, finds no place his poems for instance the "Mother" or "The Bells" in which he does not explore the theme of death. Yet as Magill (2244) perceives "Poe may be better known for his poems of longing for a lost love than for those on any other subject". Death has been his favorite topic as one of his critics says, "no American writer continuously deals on the subject, digs so deeply into it, and involves himself in the doings of death".

Contrary to his fictional world, death in his poems does not enter as 'a thief. It enters as an "intruder" someone who snatches away his beloved from him thus becomes the cause of intense pain and sorrow and inflicts the melancholy mood. As has been well commented by a number of Poe's critics his favorite female characters; Lenore, Ullalume or Annabel Lee do not represent love but are marked with death. In his poetic world death comes in the middle of the night "chilling and killing" these beautiful women. As Steinmann (1962, p. 616) comments they are 'born to die and died but to provide tenants for Poe's tombs and sepulchers and occasion for his raven to say "Nevermore" and for him to say "dark tarn" and "ghoul-haunted woodland".

Melancholy has always been the desired state of a lonely lover. As Keats says:

Ay, in the very temple of delight

Veil'd Melancholy has her Sovran shrine.

Discussing Death and melancholy in "The Philosophy of Composition" (1951, p. 368) Poe writes: "I asked myself -"Of all melancholy topics, what, according to the universal understanding of mankind, is the most melancholy?" Death - was the obvious reply". as the "most melancholy of topics". Melancholy thus, he says, is "the most legitimate of all the poetical tones".

Of all melancholy topics, Poe wanted to use the one that was universally understood and therefore he chooses death as his topic. Poe (along with other writers) believed that the death of a beautiful woman was the most poetical use of death, because it closely allies itself with Beauty.

In his essay on Ezra Pound, T. S. Eliot (1946, p. 326-338) comments: 
[...] greatness of a poet is not a question for critics of his own age to raise: it is only after he has been dead for a couple of generations that the term begins to have meaning. "Greatness" when the term means anything at all, is an attribute conferred by time.

Poe seems no exception to the rule. Despite publishing for a long time and being known to his readers as a story writer and a well known critic the greatness of Poe was not acknowledged for a long time. He could achieve literary recognition only four years before his death. The life of his literary career reaches its limits in 1845 when "The Raven" appears in the Mirror.

He publishes The Raven and Other Poems, his major volume of poetry. The plot is constructed around a lonely man the narrator of this melancholy poem who has lost his loved one, "[...] the rare and radiant maiden whom the angels name Lenore" (POE, 1951, p. 396). Poe considered sadness to be the highest manifestation of beauty. "Beauty of whatever kind in its supreme development invariably excites the sensitive soul to tears." In three of his poems "Lenore", "The Raven" and the "Annabel Lee" death becomes the cause of sadness and melancholy. The melancholy in all these poems is presented in a way that no one who reads these poems can remain untouched by it.

In "The Raven" the poet tries to ease his "sorrow for the lost Lenore", by distracting his mind with old books of "forgotten lore". The narrator is interrupted while he is "nearly napping," by a "tapping on [his] chamber door". As he opens up the door, he sees "darkness there and nothing more". Into the darkness he whispers, "Lenore", hoping his lost love had come back, but all that he hears is "an echo [that] murmured back the word 'Lenore!"'. He returns to his chamber, and this time he can hear a tapping at the window lattice. As he "flung [open] the shutter", "in [there] stepped a stately Raven", the bird of ill-omen as Poe calls it (1951), whom the narrator receives as a visitor, and "in there stepped a stately Raven... perched above my chamber door - Perched, and sat, and nothing more". The raven perched on the bust of Pallas, the goddess of wisdom in Greek mythology, above his chamber door.

In his essay "The Philosophy of Composition", he admits that in "The Raven" he combines "two ideas, of a lover lamenting his deceased Lenore and a Raven continuously repeating the word "Nevermore". Further he continues:

I first established in mind the climax, or concluding query - that to which "Nevermore" should be in the last place an answer - that in reply to which this word "Nevermore" should involve the utmost conceivable amount of sorrow and despair (1951, p. 369).

The first attribute that impresses us in "The Raven", I think, is the mysteriousness. Poe creates the mystery by the way he introduces this ill-omen bird. The 
matter goes deeper than an uncommon conversation between the raven and the narrator. However, much of the beauty of "The Raven" is derived from its melancholic tone. In a dramatic way the conversation between the bird and the narrator takes place. He asks the raven for his name, and surprisingly it answers, and croaks "Nevermore". The narrator knows that the bird does not speak from wisdom, but has been taught by "some unhappy master" and that the word "nevermore" is its only "stock and store". Though in his lonely hour he welcomes the raven as his companion but is afraid that the raven will be gone in the morning, as his "Hopes have flown before". However, the raven answers, "Nevermore" he smiles at the reply and pulls up a chair to know what the raven "meant in croaking, Nevermore". Then with the chair, where his beloved once sat, his mind turns to thoughts of his lost love, his beloved Lenore. As if in response to his painful recognition that she will not come back he suddenly imagines that there is an aura of mystical divinity about the raven:

Then, methought, the air grew denser, perfumed from an unseen censer

Swung by Seraphim whose foot-falls tinkled on the tufted floor.

Though, he perceives the irrational nature in the raven's speech, still he cannot help but ask the raven questions. Since the narrator is aware that the raven only knows one word, he can anticipate the bird's response which is always "Nevermore".

Poe's delineation of consequences of death shows its effect on his own psychic equilibrium. In "The Raven" his lament leads to the state where he can no more tolerate the bird and is forced to order:

Leave my loneliness unbroken! - quit the bust above my door!

Take thy beak from out my heart, and take thy form from off my door!

He finally accepts the truth that his "soul from out that shadow" that the raven throws on the floor, "Shall be lifted - nevermore!".

The intensity of sorrow in "The Raven" presents the death as a cause of genuine mourning and passionate grief creating an atmosphere of melancholy from which the narrator sees no way out. Raven, the unwelcomed messenger, has finally accomplished his purpose as the last stanza shows:

And the Raven, never flitting, still is sitting, still is sitting

On the pallid bust of Pallas just above my chamber door;

And his eyes have all the seeming of a demon's that is dreaming,

And the lamp-light o'er him streaming throws his shadow on the floor;

And my soul from out that shadow that lies floating on the floor

Shall be lifted - nevermore. 
In "Annabel Lee" Poe presents the abyss of melancholy brought upon by the death of his beloved which is a natural reaction. In his essay "Mourning and Melancholy" Freud (1917) treats mourning as a "reaction to the loss of a loved person [...]" he sees it as a predictable occurrence. A strong device for the melancholic tone juxtaposed with Poe's life experiences. The narrator's sorrow for the lost Annabel Lee is paralleled with Poe's own grief regarding the death of his wife. The poem was published two weeks after Poe's death and as critics have observed Annabel Lee cannot be linked only to his wife it could be any of his female friends. Yet this supposition cannot be totally ignored as the poem supports such interpretation. Line fifteen of the stanza three of the poem alludes to his first love as it reads, "So that her high kinsmen came and bore her away from me" but the last stanza, specifically the ending with the words such as the 'sepulcher' and 'tomb' leave no doubt that Annabel Lee is his beloved dead wife Virginia.

Similar to Poe, death has been a favorite theme in Emily Dickinson's poetry. In a number of her poems she knits tighter her thoughts around Death. In contrast to the profound sense of despair, sorrow and melancholy mood we see in Poe, in Miss Dickinson we get "a stress", "a buzz" or "a funeral" like state which slowly takes over her being. As has been discussed Poe sees death as the cause of separation and pain. In other words his poetic world deals with the after effects of death; the emotions and sufferings caused by Death. In Emily Dickinson it is neither the after effect nor the death of someone else or the suffering caused by death. She presents the encounter with death or in other words one's own experience of 'dying. The expression of witnessing and experiencing the phenomena of death in her poems comes as a personal process of extinction. This slow degradation is very acute in her poem "Dying" where the poetess writes:

My feet kept drowsing, drowsing still;

My fingers were awake;

Yet why so little sound myself

Unto my seeming make?

She does not distract her reader but takes him to follow her in this experience of "Dying", as from the numbing feet she moves to her vision and shares the loss of sight. Further she writes:

How well I knew the light before!

I could not see it now

And she knows,

"T is dying, I am doing;"

In a letter, written in September 1846 to her friend Abiah Root, Emily Dickinson (1958, p. 415) confessed her inability to imagine her own death but this was a young girl of fifteen. The poems dealing with the idea of 'her own' death defi- 
nitely were written in the later stage of her life. A number of poems such as "Dying", "I heard a Fly buzz", "A Funeral in the brain" give voice to the sensation and the feeling of one's own dying. In all these poems she deals with acute sense of pain but this pain is not born out of the sufferings caused by someone else's death as we see in Poe but it presents the feeling of going through the dying process. As Ransom (1956) calls it, they present the "previsions of her own death". His observation makes sense as we compare Poe and Dickinson. None of these poems by Emily Dickinson present death as "absolute in some brutal majesty" nor in the "role of God's dreadful minister" as we see in Poe. What she tries to do is to represent the emotional changes of her being as and when she goes through various levels of this process of dying.

In her poem "I heard a Fly buzz" Emily Dickinson, first, presents the sufferings of a dying person then she moves to the people around her and imagines how they will struggle to save her from death. Here she comes close to Poe as she sees death in form of an unwelcomed guest. She also emphasises the before death experience, the serene tranquil moment where she is concerned about others and at the same time is the centre of attention. The fly's buzz here is marked as "blue, uncertain, stumbling", and emphasises the unpleasant external situation one goes through this final hour where the buzzing fly serves as a reminder. The first stanza of the poem emphasises the struggle for life as it reads "Between the Heaves of Storm -" which finally ends in the deadly "Stillness" and whole world simply fades away from her eyes. The last line more strongly shows the fading away of the consciousness, "and then I could not see to see".

It can be argued here, if it was possible to envision one's own death? The answer might be no. However, the picture she draws here very vividly sketches the internal as well as the external aspect of death.

The poem "I felt a Funeral, in my Brain" apparently draws a scene where funeral services are being performed. Here she presents death as a state of growing unconscious and uses funeral to represent the sensation that a part of her is dying. There have been multiple readings of this poem. For Charles R. Anderson (1990) the poem presents 'an ironic reversal of the conventional attitudes of her time and place toward the significance of the moment of death' whereas for Paul Bennett (1990) it is "ironically mocking". The funeral presents death as the passage from one state to another; life to death. Death here is not portrayed as a moment of rupture. The loss itself cedes quickly to the work of mourning necessary to the surviving individuals.

Here the poet is not only observing the funeral but is also feeling it hence she is both the observer and the participant at the same time. The ritual attempts to close the gap between reality and thought can actually replace or at least reintegrate 
the lost being. The ceremonial ritual includes words which in the last line of the poem highlight the destructive aspect of death as it reads:

And then a Plank in Reason, broke, representing the shattered self.

An even more dramatic example is the poem "Because I could not for Death". In this poem she constructs an image that redeems the eternal fear from death. Rather than turning to the sadness or terror created by the idea of death she turns to a life affirming example and transforms the deathly feeling in a gradual change of life. She is incomparable in her attempt to transform death into a threshold experience. This connection between life and death drive makes one to recall Freud's earlier assertions that "The goal of life is death [...] the deferment of death is due to circumstances and stimuli imposed by the external world."

Commenting on "Because I could not stop for Death" Thomas H. Johnson (1955, p. 222), her biographer writes:

In 1963 Death came in full stature as a person. "Because I could not stop for Death" is a superlative achievement wherein Death becomes one of the great characters of literature. [...] Dickinson envisions Death as a person she knew and trusted, or believed that she could trust.

Johnson's observation highlights the stark difference we find between these two poets. In Poe, death could never occupy the place of 'a known person' or of 'a trusted friend' as it does in Dickinson's world. Death for her is not an 'intruder', not 'a thief' as is presented by Poe but a companion in whom she can trust. This trust and companionship with death, in the poem "Because I could not stop for Death", makes her draw a picture where a young lady in bride's dress is being carried to her final journey. As Anderson (1960, p. 242) observes, "'Death', usually rude, sudden, and impersonal, has been transformed into a kindly and leisurely gentleman [...]. But this figure of a gentleman taking a lady for a carriage ride is carefully underplayed and then dropped after two stanzas." Again we see the difference in two poets as they use opposite adjectives 'kind' and 'gentle' offer a clear contrast to Poe's 'cruel' and 'chilling'. In third stanza Dickinson comes close to Poe as she says 'the sun passed them' and the poet realizes that the 'kind' companion is taking her towards an unkind ambient; the cold and damp grave. She feels the chill in her 'Gossamer' and her 'Tulle'. The grave makes her to feel that the death was not all that warmth as it appeared at first.

"Because I could not stop for Death" has been acclaimed by the critics as a beautiful narrative of the process of dying. In this poem we see no effort to make reader acquainted with death. Miss Dickinson does not try to describe death and the reader knows nothing of its appearance as it is not the Death Dickinson is interested in, her interest lies in the person who is dying and who is casting a last 
glance at the world which has been part of her life. Hence the poem is divided in three moments; childhood, youth, and the final rest. The narrator is aware of the final rest but wants to cast a last glance at what life had been till that moment. In other words what Dickinson is dealing with here is the dialectic experience of "living dying" (borrowing the term used by Guenther).

My discussion of the representation of the death highlights the similarities and differences in the treatment of same theme by these two poets. The comparison helps to illustrate some of the different roles and manifestations which they assume while dealing with the death. In Poe each word is structured almost completely as a simple sequence of nouns, always signifies the loss or "Nevermore" the only word the raven utters. In "Lenore" and "Annabel Lee", specifically, we can note the impact of a poetics of music, very much the style of Poe which is hard to find in Miss Dickinson's poetry.

We can say that despite the difference of focus from which they treat and present the death both Poe and Dickinson share a common point. In both poets the death is not presented as something scary or horrific hence what is missing in both poets is the fear from death. Specifically in Dickinson the traumatic experience in a poetic depiction transforms into familiar and the death appears as a natural concept. Her manner of dealing with death differs from conventional attitudes towards death. She replaces the familiar death bed scene, changes the adjectives, normally used to depict these scenes, and is able to create a sense of peace in her readers mind.

Whether it is the sense of loss or the sense of dying as we see in these two poets we can affirm in Guenther's (1996, p. 102) words that "a writer is able to write about death, it seems, only at the cost of his own life".

Concluding my discussion I cite from Poe's poem "Doomed City" as he writes:

Hell rising from a thousand thrones

Shall do it reverence,

And Death to some more happy clime

Shall give his undivided time. 


\section{REFERENCES}

ANDERSON, Charles R. Emily Dickinson's Poetry: Stairway of Surprise. New York: Holt, Rinehart and Winston, 1960.

BARTHES, Roland. Textual Analysis: Poe's Valdemar. In: LODGE, David. (Ed.). Modern Criticism and Theory. New York: Longman, 1988.

BENNETT, Paul. Emily Dickinson, Woman Poet. 1990. Letters, 1958, II, 415.

BASSNETT, Susan. Comparative Literature: A Critical Introduction. Oxford: Blackwell, 1993.

BRADLEY, Scully, et al. (Ed). Edgar Allan Poe. The American Tradition in Literature. 2 vols. New York: Norton, 1961, v. 1, p. 737-892.

ELIOT, T. S. Ezra Pound. Poetry, n. LXVII, Sept. 1946.

FREUD, Sigmund. Jenseits des Lustprinzips. In Psychologie des Unbewussten, Band III. Frankfurt a. M., 1975, p. 213-72.

GLENN, Eunice. Emily Dickinson's Poetry: A Revaluation. The Sewanee Review, n. LI, autumn 1943.

GUENTHER, Beatrice Marina. The Poetics of Death: the short Prose of Kleist and Bazac. New York: SUNY, 1996.

FRANK, Armin Paul. On the Comparison of Interlitrary Configurations. CLCWeb: Comparative Literature and Culture, n. 3, v. 2, June 2001.

FRANKLIN, R. W. (Ed.). The Poems of Emily Dickinson. Cambridge. Mass.: The Belknap Press of Harvard University Press, 1998.

JOHNSON, Thomas H. Emily Dickinson: An Interpretative Biography. Cambridge, Mass.: Harvard Univ. Press, 1955.

KOELB, Clayton; NOAKES, Susan. (Ed.). The Comparative Perspective on Literature. Itchaca: Cornell University Press, 1988.

MAGILL, Frank N. (Ed.). Edgar Allan Poe. Critical Survey of Poetry. 8 vols. Englewood Cliffs, NJ: Salem, 1982, v. 5, p. 2239-2248.

MYERSON, Joel. (Ed.). Edgar Allan Poe. In Dictionary of Literary Biography. 201 vols. Detroit: Gale, 1977, v. 3, p. 249-297.

DOREN, Stern, Philip Van. (Ed.). The Tell-Tale Heart and Other Writings by Edgar Allan Poe. New York: Bantam, 1982.

PEARL, Matthew. The Poe Shadow. Random House: London, 2006.

PRAWER, S. S. Comparative Literary Studies: an Introduction. London: Duckworth, 1973.

RANSOM, John Crowe. Emily Dickinson: A Poet Restored. Perspectives USA, 1956.

STEINMANN, Martin Jr.; WILLEN, Gerald. (Ed.). Literature for Writing: An Anthology of Major British and American Authors. California: Wadswoth, 1962.

MABBOTT, T. O. (Ed.). Selected Poetry and Prose of Poe. New York: Random House, 1951.

UNGER, Leonard. (Ed). Edgar Allan Poe. American Writers. 4 vols. New York: Scribner, 1972.

Web Journal by E. A. Poe Society of Baltimore. Disponível em: www.eapoe.org. 
